\title{
Length of hospital stay of COVID-19 patients and its relationship with liver function abnormalities
}

\author{
Shishir Sikto Sarker, SM Ali Hasan, Md Sarower Islam, Nimai Das, Kazi Monisur Rahman, \\ Md Razibul Alam, Md Anwarul Kabir
}

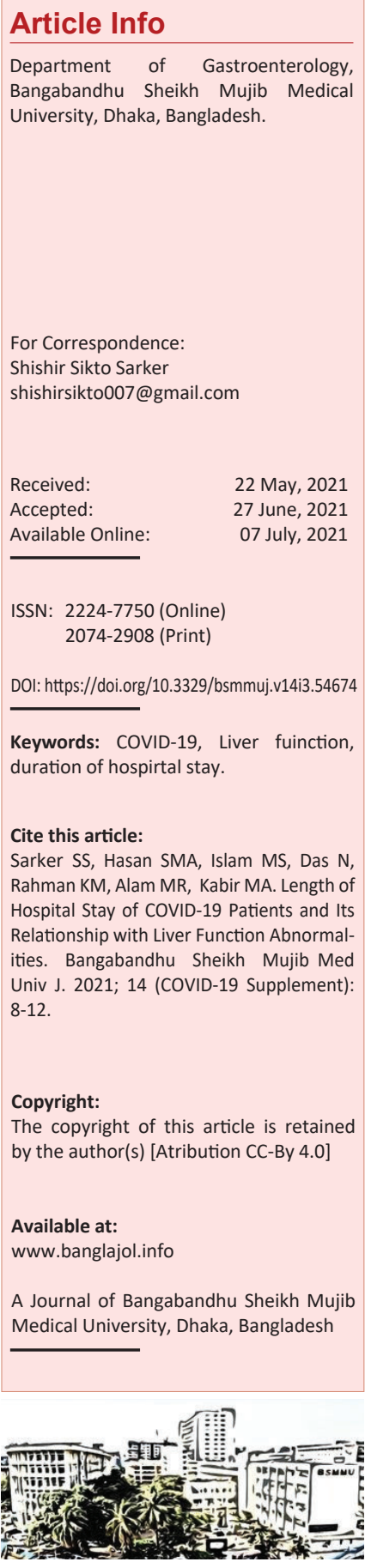

\begin{abstract}
Corona Virus Disease (COVID-19), a threat to global public health, caused by severe acute respiratory syndrome corona virus 2 (SARS-CoV-2) has now spread to more than two hundred countries in the world. This ongoing pandemic has already been exhausted our health care systems. So determining or predicting the need of healthcare resources has now become a number one priority and the length of hospitalization is a scale which represents the function of the health system of countries. Our objectives were to see the length of hospital stay of COVID-19 patients and its relationship with liver function abnormalities. This observational cross-sectional study was carried out in the COVID-19 inpatient department of BSMMU on 96 patients who are RT-PCR positive for severe acute respiratory syndrome coronavirus 2 (SARS-CoV-2). Liver function abnormalities (ALT, AST, ALP, PT, serum bilirubin and serum albumin) were recorded precisely. Length of hospital stay was documented. Occurrence of liver function abnormalities and their relation with length of hospital stay were assessed statistically. Total 96 patients were included. Mean hospital stay was found to be $14.0 \pm 6.2$ with range from 5.0 to 33 days. Total $49(51.0 \%)$ patients required hospital staying $\leq 14$ days and $47(49 \%)$ patients were found hospital stay $>14$ days. Mean length of hospital stay in case of mild COVID-19 patients was $6.76 \pm 1.12$ days, in case of moderate Covid-19 patients was $12.22 \pm 1.91$ days and in severe group it was 19.18 \pm 4.81 days. The mean length of hospital stay was statistically significant with raised ALT (18.9 \pm 6.2$)$, raised AST(18.9 \pm 5.9$)$ and low serum albumin $(19.4 \pm 7.1)$ group $(p<0.05)$. No significant association was found between mean length of hospital stay and raised ALP, PT and S. bilirubin group. This study showed that length of hospital stay were significantly higher among severe COVID-19 patients and among liver function abnormalities raised ALT, raised AST and low serum albumin were associated with significant longer hospital stay. Assessing the length of hospital stay is helpful in understanding and predicting hospital bed demand and optimizing the use of healthcare resources.
\end{abstract}

\section{Introduction}

A newly emerging infectious disease named Coronavirus disease 2019 (COVID-19) has become a global public health issue caused by severe acute respiratory syndrome corona virus (SARS-CoV-2). This ongoing pandemic which may develop to acute respiratory distress syndrome or multiple organ failure was first identified in December 2019 in Wuhan, Hubei, China. ${ }^{1}$ According to current estimate up to $15-18 \%$ of patients may become severe or critically ill, less than $5 \%$ case become fatal, some of them require intensive care unit care. ${ }^{2}$ Most commonly reported symptoms are respiratory tract manifestations in patients with COVID-19. ${ }^{3}$ Many case series have also been reported variable involvement of GI and hepatic involvement apart from respiratory system involvement. ${ }^{4}$ Significantly higher risk of liver function abnormalities seen in those with severe disease than in those with non severe disease. Among the deceased persons the incidence of liver injury might reach as high as $78 \% .^{5}$

Due to rapid outbreak of COVID-19, health care facilities are now challenged by the huge number of patients influx into hospital. According to WHO, till 18th June, 2021 more than 178 million confirmed cases have been registered with a death toll of 3.86 million 
worldwide. In Bangladesh till now total confirmed cases are 844,970 and the number of total deaths are 13,399. Even developed countries with their highly efficient health care facilities greatly stressed and suffered from high death tolls.

For decision making and proper planning, it is important to understand and predict hospital bed demand. ${ }^{6}$ Length of hospitalization is a scale representing the function of the health system of countries. To determine the ongoing needs for healthcare resources (bad, staff, oxygen) has become the number one priority for many countries. In one study, median length of hospital stay ranged from 4 to 53 days within china and 4 to 21 days outside of China. ${ }^{6}$ Guo et al. in their study found median length of hospital stay was 10-13 days. ${ }^{7}$ Length of hospital stay differs due to various risk factors as well as the geographic setting due to varying COVID-19 care guidelines. ${ }^{6}$ Among the number of risk factors, raised ALT and AST was addressed as an independent predictors of length of hospital stay. ${ }^{8}$

To find out the length of hospital stay and its relationship with liver function abnormalities, we conducted a cross sectional study on patients hospitalized with COVID-19 in COVID inpatient unit, Bangabandhu Sheikh Mujib Medical University, Dhaka.

\section{Methods}

This is a cross sectional study carried out at dedicated COVID-19 unit of Bangabandhu Sheikh Mujib Medical University, Dhaka, Bangladesh. The study period was August, 2020 to January 2021.

\section{Inclusion Criteria:}

Total 96 RT-PCR positive COVID 19 patients aged $\geq 18$ years were included as study sample.

\section{Exclusion Criteria:}

Patients with age less than 18 years and who does not understand or agree to comply with planned study procedure were excluded from our study.

\section{Study Procedure:}

Patients suffering from SARS-CoV-2 infection confirmed by RT- PCR admitted in COVID-19 inpatient department were enrolled in the study after screening for inclusion and exclusion criteria. RT-PCR negative COVID-19 patients and those with known pre-exisitng liver disease were excluded. Demographic profile, precise date of initiation of symptoms of these patients was noted in data sheet. To assess liver function, ALT, AST, ALP, s. bilirubin, prothrombin time and s. albumin were done and noted precisely in data sheet. Liver function abnormalities were defined as: ALT > $40 \mathrm{U} / \mathrm{L}, \mathrm{AST}>40 \mathrm{U} / \mathrm{L}$, ALP $>120 \mathrm{U} / \mathrm{L}$, serum bilirubin $>1.2 \mathrm{mg} / \mathrm{dl}$, prothrombin time prolonged $>4$ second and serum albumin $<35 \mathrm{gm} / \mathrm{L}$. COVID 19 disease severity was assessed and classified as mild, moderate, severe and critical cases by concerned Internal
Medicine \& Pulmonology specialist consultant in accordance with the Interim Guidance, 27 ${ }^{\text {th }}$ May, 2020 on the Management of COVID 19 from WHO (WHO, 2020). Total duration of hospital stay was documented. We only included patients with normal discharge circumstances and excluded those with death outcomes. Occurrence of liver function abnormalities and their relation with duration of hospital stay was assessed statistically.

\section{Statistical analysis:}

Statistical analyses were carried out by using the Statistical Package for Social Sciences version 23.0 for Windows (SPSS Inc., Chicago, Illinois, USA). The mean values were calculated for continuous variables. The quantitative observations were indicated by frequencies and percentages. Unpaired t-test was used for continuous variables. P values $<0.05$ were considered as statistically significant.

\section{Result:}

Total 96 patients were included in this study. Two third (66.7\%) patients were male and 32(33.3\%) were female. Male female ratio was $2: 1$. Of them, 37(38.5\%) patients belonged to age $51-60$ years. The mean age was found $57.2 \pm 12.1$ years with range from 20 to 86 years. (Table I)

Table-I

\begin{tabular}{|c|c|c|}
\hline \multicolumn{2}{|c|}{$\begin{array}{c}\text { Distribution of the study patients by demographic } \\
\text { characteristics (n=96) }\end{array}$} \\
\hline $\begin{array}{l}\text { Socio-demographic } \\
\text { characteristics }\end{array}$ & $\begin{array}{c}\text { Number of } \\
\text { patients (n) }\end{array}$ & $\begin{array}{c}\text { Percentage } \\
(\%)\end{array}$ \\
\hline Age (years) & & 2.1 \\
\hline$\leq 30$ & 2 & 8.3 \\
\hline $31-40$ & 8 & 14.6 \\
\hline $41-50$ & 14 & 38.5 \\
\hline $51-60$ & 37 & 222.9 \\
\hline $61-70$ & 11 & 11.5 \\
\hline $71-80$ & 2 & 2.1 \\
\hline$>80$ & & $57.2 \pm 12.1$ \\
\hline $\begin{array}{l}\text { Mean } \pm \text { SD } \\
\text { Range (min-max) }\end{array}$ & 64 & \\
\hline Sex & 32 & \\
\hline Male & \multicolumn{2}{|c|}{} \\
\hline Female & \multicolumn{2}{|c|}{} \\
\hline
\end{tabular}

This study showed that $44(45.8 \%)$ patients had severe, 27 (28.1\%) patients had moderate and $25(26.0 \%)$ had mild COVID-19 disease. (Table II) 


\begin{tabular}{|l|c|c|}
\hline \multicolumn{2}{|c|}{ Table-II } \\
\hline \multicolumn{2}{|c|}{$\begin{array}{c}\text { Distribution of the study patients according to severity of } \\
\text { COVID-19 diseases (n=96) }\end{array}$} \\
\hline COVID-19 diseases & $\begin{array}{c}\text { Number of } \\
\text { patients (n) }\end{array}$ & $\begin{array}{c}\text { Percentage } \\
(\%)\end{array}$ \\
\hline Mild & 25 & 26.0 \\
\hline Moderate & 27 & 28.1 \\
\hline Severe & 44 & 45.8 \\
\hline
\end{tabular}

In our study mean hospital stay was found to be $14.0 \pm 6.2$ with range from 5.0 to 33 days. Total $49(51.0 \%)$ patients required hospital staying $\leq 14$ days and $47(49 \%)$ patients were found hospital stay $>14$ days. (Table III).

\begin{tabular}{|lc|c|}
\hline \multicolumn{3}{|c|}{ Table-III } \\
\hline \multicolumn{2}{|c|}{$\begin{array}{c}\text { Distribution of the study patients according to hospital } \\
\text { stay (n=96) }\end{array}$} \\
\hline Hospital stay (days) & $\begin{array}{c}\text { Number of } \\
\text { patients (n) }\end{array}$ & $\begin{array}{c}\text { Percentage } \\
(\%)\end{array}$ \\
\hline$\leq 14$ & 49 & 51.0 \\
\hline$>14$ & 47 & 49.0 \\
\hline Mean \pm SD & 14.0 & \pm 6.2 \\
\hline
\end{tabular}

Mean length of hospital stay in case of mild COVID-19 patients was $6.76 \pm 1.12$ days, in case of moderate Covid-19 patients was $12.22 \pm 1.91$ days and in severe group it was 19.18 \pm 4.81 . ( Table IV)

\begin{tabular}{|l|c|c|}
\hline \multicolumn{2}{|c|}{ Table-IV } \\
\hline \multirow{2}{*}{$\begin{array}{l}\text { Length of Hospital Stay according to severity of COVID-19 } \\
\text { diseases ( } \mathbf{n}=96)\end{array}$} \\
\hline \multirow{2}{*}{ COVID-19 diseases } & \multicolumn{1}{|c|}{ Length of hospital stay } \\
\cline { 2 - 3 } & Mean \pm SD & Range \\
\hline Mild & $6.76 \pm 1.12$ & $5-10$ \\
\hline Moderate & $12.22 \pm 1.91$ & $10-16$ \\
\hline Severe & $19.18 \pm 4.81$ & $6-33$ \\
\hline
\end{tabular}

In our study median ALT was $36.0 \mathrm{U} / \mathrm{L}$ (range 13-355), AST was 35.0 U/L (range 17-170), ALP was 87.5 U/L (range 56-15), prolonged prothrombin time was 0.8 second (range 0-7.2), serum bilirubin was $0.64 \mathrm{mg} / \mathrm{dL}$ (range 0.30-3.1) and serum albumin was $37.0 \mathrm{~g} / \mathrm{L}$ (range 25-43). Raised ALT (>40 U/L) was found in $37.5 \%$, Raised AST (>40 U/L) was found in $39.6 \%$, Raised ALP (>120 U/L) was found in 1\%, Raised Serum Bilirubin $(>1.2 \mathrm{mg} / \mathrm{dL})$ was found in $2.1 \%$, Low Serum Albumin $(<35 \mathrm{~g} / \mathrm{L})$ was found in $18.8 \%$ cases. (Table V)
Table-V

\section{Distribution of the study patients according to liver function abnormality $(\mathrm{n}=96)$}

\begin{tabular}{|c|c|c|}
\hline Laboratory variables & $\begin{array}{l}\text { Number of } \\
\text { patients (n) }\end{array}$ & $\begin{array}{c}\text { Percentage } \\
(\%)\end{array}$ \\
\hline \multicolumn{3}{|l|}{ ALT } \\
\hline Raised (>40 U/L) & 36 & 37.5 \\
\hline Normal (0-40 U/L) & 60 & 62.5 \\
\hline Median & \multicolumn{2}{|c|}{36.0} \\
\hline Range (min-max) & \multicolumn{2}{|c|}{$13.0-355.0$} \\
\hline \multicolumn{3}{|l|}{ AST } \\
\hline Raised (>40 U/L) & 38 & 39.6 \\
\hline Normal (0-40 U/L) & 58 & 60.4 \\
\hline Median & \multicolumn{2}{|c|}{35.0} \\
\hline Range (min-max) & \multicolumn{2}{|c|}{$17.0-170.0$} \\
\hline \multicolumn{3}{|l|}{ ALP } \\
\hline Raised (>120 U/L) & 1 & 1.0 \\
\hline Normal (40-120 U/L) & 95 & 99.0 \\
\hline Median & \multicolumn{2}{|c|}{87.5} \\
\hline Range (min-max) & \multicolumn{2}{|c|}{$56.0-145.0$} \\
\hline \multicolumn{3}{|l|}{ Prothrombin Time (PT) } \\
\hline Raised (>4 sec) & 9 & 9.4 \\
\hline Normal (0-4 sec) & 87 & 90.6 \\
\hline Median & \multicolumn{2}{|c|}{0.8} \\
\hline Range (min-max) & \multicolumn{2}{|c|}{$0.0-7.2$} \\
\hline \multicolumn{3}{|l|}{ Serum Bilirubin } \\
\hline Raised (>1.2 mg/dL) & 2 & 2.1 \\
\hline Normal (0.3-1.2 mg/dL) & 94 & 97.9 \\
\hline Median & \multicolumn{2}{|c|}{0.64} \\
\hline Range (min-max) & \multicolumn{2}{|c|}{$0.30-3.1$} \\
\hline \multicolumn{3}{|l|}{ Serum Albumin } \\
\hline Low $(<35 \mathrm{~g} / \mathrm{L})$ & 18 & 18.8 \\
\hline Normal (35-55 g/L) & 78 & 81.3 \\
\hline Median & \multicolumn{2}{|c|}{37.0} \\
\hline Range (min-max) & \multicolumn{2}{|c|}{$25.0-43.0$} \\
\hline
\end{tabular}

Our study shows that mean hospital stay was $18.9 \pm 6.2$ days in patients with raised ALT and $11.0 \pm 4.0$ days in patients with normal ALT. The difference was statistically significant $(p<0.05)$ between two groups. (Table VI) 


\section{Table-VI}

Association between ALT with hospital staying (n=96)

\begin{tabular}{|l|c|c|c|}
\hline \multirow{2}{*}{} & \multicolumn{2}{|c|}{ ALT } & p value \\
\cline { 2 - 3 } & $\begin{array}{c}\text { Raised } \\
(\mathrm{n}=36) \\
\text { Mean } \pm \text { SD }\end{array}$ & $\begin{array}{c}\text { Normal } \\
(\mathrm{n}=60) \\
\text { Mean } \pm \text { SD }\end{array}$ & \\
\hline Hospital staying (days) & $18.9 \pm 6.2$ & $11.0 \pm 4.0$ & \multirow{2}{*}{0.011} \\
\cline { 1 - 3 } Range (min-max) & $6.0-33.0$ & $5.0-18.0$ & \\
\hline
\end{tabular}

This study observed that mean hospital stay was found $18.9 \pm 5.9$ days in patients with raised AST and $10.7 \pm 4.0$ days in patients with normal AST. The difference was statistically significant $(\mathrm{p}<0.05)$ between two groups. (Table VII)

\section{Table-VII}

Association between AST with hospital staying ( $n=96)$

\begin{tabular}{|l|c|c|c|}
\hline \multirow{2}{*}{} & \multicolumn{2}{|c|}{ AST } & p value \\
\cline { 2 - 3 } & $\begin{array}{c}\text { Raised } \\
(\mathrm{n}=38) \\
\text { Mean } \pm \text { SD }\end{array}$ & $\begin{array}{c}\text { Normal } \\
(\mathrm{n}=58) \\
\text { Mean } \pm \text { SD }\end{array}$ & \\
\hline Hospital staying (days) & $18.9 \pm 5.9$ & $10.7 \pm 4.0$ & \multirow{2}{*}{0.001} \\
\hline Range (min-max) & $6.0-33.0$ & $5.0-18.0$ & \\
\hline
\end{tabular}

In our study mean hospital stay was $6.0 \pm$ days in patients with raised ALP and 14.1 \pm 6.2 days in patients with normal ALP which is not statistically significant. In case of raised prothrombin group mean hospital stay was $17.2 \pm 7.0$ days and $13.7 \pm 6.1$ days in patients with normal prothrombin time. The difference was not statistically significant $(\mathrm{p}>0.05)$ between two groups. ( Table VIII \& IX)

\section{Table-VIII}

Association between ALP with hospital staying (n=96)

\begin{tabular}{|c|c|c|c|}
\hline & \multicolumn{2}{|c|}{ ALP } & \multirow[t]{2}{*}{$p$ value } \\
\hline & $\begin{array}{c}\text { Raised } \\
(n=1) \\
\text { Mean } \pm S D\end{array}$ & $\begin{array}{c}\text { Normal } \\
(\mathrm{n}=95) \\
\text { Mean } \pm \mathrm{SD}\end{array}$ & \\
\hline Hospital staying (days) & $6.0 \pm$ & $14.1 \pm 6.2$ & \multirow[t]{2}{*}{ - } \\
\hline Range (min-max) & $6.0-6.0$ & $5.0-33.0$ & \\
\hline
\end{tabular}

\section{Table-IX}

Association between prothrombin time with hospital staying $(n=96)$

\begin{tabular}{|l|c|c|c|}
\hline \multirow{2}{*}{} & \multicolumn{2}{|c|}{ Prothrombin time } & p value \\
\cline { 2 - 3 } & $\begin{array}{c}\text { Raised } \\
(\mathrm{n}=9) \\
\text { Mean } \pm \text { SD }\end{array}$ & $\begin{array}{c}\text { Normal } \\
(\mathrm{n}=87) \\
\text { Mean } \pm \text { SD }\end{array}$ & \\
\hline Hospital staying (days) & $17.2 \pm 7.0$ & $13.7 \pm 6.1$ & \multirow{2}{*}{0.618} \\
\hline Range (min-max) & $6.0-27.0$ & $5.0-33.0$ & \\
\hline
\end{tabular}

This study shows that mean hospital stay was $15.5 \pm 13.4$ days in patients with raised serum bilirubin and $14.0 \pm 6.1$ days in patients with normal serum bilirubin group. The difference was not statistically significant $(p>0.05)$ between two groups. ( Table X)

\begin{tabular}{|c|c|c|c|}
\hline \multicolumn{4}{|c|}{ Table-X } \\
\hline \multicolumn{4}{|c|}{$\begin{array}{l}\text { Association between serum bilirubin with hospital staying } \\
\qquad(\mathrm{n}=96)\end{array}$} \\
\hline & \multicolumn{2}{|c|}{ Serum bilirubin } & \multirow[t]{2}{*}{$\mathrm{p}$ value } \\
\hline & $\begin{array}{c}\text { Raised } \\
(n=2) \\
\text { Mean } \pm S D\end{array}$ & $\begin{array}{c}\text { Normal } \\
(\mathrm{n}=94) \\
\text { Mean } \pm \text { SD }\end{array}$ & \\
\hline Hospital staying (days) & $15.5 \pm 13.4$ & $14.0 \pm 6.1$ & \multirow[t]{2}{*}{0.731} \\
\hline Range (min-max) & $6.0-25.0$ & $5.0-33.0$ & \\
\hline
\end{tabular}

In this study mean hospital stay was $19.4 \pm 7.1$ days in patients with low serum albumin and $12.7 \pm 5.3$ days in patients with normal serum albumin. The difference was statistically significant $(\mathrm{p}<0.05)$ between two groups. (Table XI)

\section{Table-XI}

Association between serum albumin with hospital staying $(n=96)$

\begin{tabular}{|c|c|c|c|}
\hline & \multicolumn{2}{|c|}{ Serum albumin } & \multirow[t]{2}{*}{$\mathrm{p}$ value } \\
\hline & $\begin{array}{c}\text { Raised } \\
(\mathrm{n}=18) \\
\text { Mean } \pm \text { SD }\end{array}$ & $\begin{array}{c}\text { Normal } \\
(\mathrm{n}=78) \\
\text { Mean } \pm \text { SD }\end{array}$ & \\
\hline Hospital staying (days) & $19.4 \pm 7.1$ & $12.7 \pm 5.3$ & \multirow[t]{2}{*}{0.001} \\
\hline Range (min-max) & $6.0-33.0$ & $5.0-26.0$ & \\
\hline
\end{tabular}

\section{Discussion:}

The objective of the study was to see the length of hospital stay of COVID-19 patients and its relationship with liver function abnormalities. We included 96 patients for this study from COVID-19 inpatient unit of BSMMU.

In our study 37 (38.5\%) patients belonged to age 51-60 years. The mean age was found 57.2 \pm 12.1 years with range from 20 to 86 years. $64(66.7 \%)$ patients were male and $32(33.3 \%)$ were female. Male female ratio was 2:1. This study showed that 44 $(45.8 \%)$ patients had severe, $27(28.1 \%)$ patients had moderate and $25(26.0 \%)$ had mild COVID-19 disease.

In our study mean hospital stay was found to be $14.0 \pm 6.2$ with range from 5.0 to 33 days. Total $49(51.0 \%)$ patients required hospital staying $\leq 14$ days and $47(49 \%)$ patients were found hospital stay $>14$ days. In case of mild COVID-19 patients mean length of hospital stay was $6.76 \pm 1.12$ days, in case of moderate Covid-19 patients it was $12.22 \pm 1.91$ days and in 
severe cases it was $19.18 \pm 4.81$ days. Rees et al showed in their study that median hospital length of stay ranged from 4 to 53 days within china and 4 to 21 days outside of china. ${ }^{6}$ Guo et al conducted a retrospective cohort study about risk factors associated with hospital length of stay in patients with COVID-19. They observed median length of stay in hospital was 17 days. Chen et al. showed median length of stay was 18 days in their study. ${ }^{9}$

In this study we found that median ALT was 36.0 U/L, AST was $35.0 \mathrm{U} / \mathrm{L}$, ALP was $87.5 \mathrm{U} / \mathrm{L}$, prolonged prothrombin time was 0.8 second, serum bilirubin was $0.64 \mathrm{mg} / \mathrm{dL}$ and serum albumin was $37.0 \mathrm{~g} / \mathrm{L}$. Raised ALT (>40 U/L) was found in $37.5 \%$ cases, raised AST $(>40 \mathrm{U} / \mathrm{L})$ was found in $39.6 \%$ cases, raised ALP (>120 U/L) was found in $1 \%$, raised $\mathrm{s}$. bilirubin $(>1.2 \mathrm{mg} / \mathrm{dL})$ was found in $2.1 \%$, low s. albumin $(<35 \mathrm{~g} / \mathrm{L})$ was found in $18.8 \%$ cases. Su et al. in 2020 reported that the incidence of liver injury in patients with COVID-19 was reported as $39.6 \%$ to $43.4 \%$, manifested mainly by the elevation of alanine aminotransferase (ALT) and aspartate aminotransferase (AST) levels, as well as hypoalbuminemia [10]. A few patients had a slight increase in total bilirubin (TBIL) level. This finding is almost consistent to our findings.

In this study mean hospital stay was found $18.9 \pm 6.2$ days in raised ALT group and 11.0 \pm 4.0 days in normal ALT group. The difference was statistically significant $(p<0.05)$ between two groups. The mean hospital stay was found $18.9 \pm 5.9$ days in raised AST group and 10.7 \pm 4.0 days in normal AST group. The difference was statistically significant $(p<0.05)$ between two groups. The mean hospital stay was found $6.0 \pm$ days in raised ALP and 14.1 \pm 6.2 days in normal ALP group. The mean hospital stay was found $17.2 \pm 7.0$ days in raised prothrombin time and $13.7 \pm 6.1$ days in normal prothrombin time group. The difference was not statistically significant $(\mathrm{p}>0.05)$ between two groups. The mean hospital stay was found 15.5 \pm 13.4 days in raised serum bilirubin and 14.0 \pm 6.1 days in normal serum bilirubin group. The difference was not statistically significant $(p>0.05)$ between two groups. The mean hospital stay was found 19.4 \pm 7.1 days in low serum albumin and $12.7 \pm 5.3$ days in normal serum albumin. The difference was statistically significant $(p<0.05)$ between two groups. Among the number of risk factors, raised ALT and AST was addressed as an independent predictors of length of hospital stay in a study conducted by $\mathrm{Li}$ et al. ${ }^{8}$ This observation is consistent with findings in our study.

\section{Conclusion :}

This study showed that length of hospital stay were significantly higher among severe COVID-19 patients and among liver function abnormalities raised ALT, raised AST and low serum albumin were associated with significant longer hospital stay. Assessing the length of hospital stay is helpful in understanding and predicting hospital bed demand and optimizing the use of health care resources. Though it was a single centered study and sample size was small, further studies should be done including large number of patients and involving multiple center.

\section{References}

1. Wan S, Xiang YI, Fang W, Zheng Y, Li B, Hu Y. Clinical features and treatment of COVID-19 patients in northeast Chongqing. Journal of medical virology. 2020; 92(7): 797-806.

2. Sun P, Qie S, Liu Z, Ren J, Li K, Xi J. Clinical charactristics of hospitalized patients with SARS-CoV-2 infection: a single arm meta-analysis. Journal of Medical Virology. 2020; 92: 612-7.

3. Guan WJ, Ni ZY, Hu Y, Liang WH, Ou CQ, He JX, et al. Clinical characteristics of coronavirus disease 2019 in China. New England Journal of Medicine. 2020; 382:1708-1720.

4. Kumar A, Arora A, Sharma P, Anikhindi SA, Bansal N, Singla V, et al. Gastrointestinal and hepatic manifestations of Corona Virus Disease-19 and their relationship to severe clinical course: A systematic review and meta-analysis. Indian Journal of Gastroenterology. 2020;39(3):268-284.

5. Zhang Y, Zheng L, Liu L, Zhao M, Xiao J, Zhao Q. Liver impairment in COVID-19 patients: A retrospective analysis of 115 cases from a single centre in Wuhan city, China. Liver international. 2020; 40(9):2095-2103.

6. Rees EM, Nightingale ES, Jafari Y, Waterlow NR, Clifford S, Pearson CAB, et al. COVID-19 length of hospital stay: a systematic review and data synthesis. BMC Medicine. 2020;18(1):270.

7. Guo A, Lu J, Tan H, Kuang Z, Luo Y, Yang T, et al. Risk factors on admission associated with hospital length of stay in patients with COVID-19: a retrospective cohort study. Sci Rep. 2021 Mar 31;11(1):7310.

8. Li K, Zhang C, Qin L, Zang C, Li A, Sun J, et al. A nomogram prediction of length of hospital stay in patients with COVID-19 pneumonia: A retrospective cohort study. Disease Markers. 2021;2021:1-9.

9. Chen F, Li F, Zheng J, Zhou R, Liu H, Wu K, et al. Factors associated with duration of hospital stay and complications in patients with COVID-19. Journal of Public Health and Emergency. 2021;5:1-12.

10. Su S, Shen J, Zhu L, Qiu Y, He JS, Tan JY, et al. Involvement of digestive system in COVID-19: manifestations, pathology, management and challenges. Therapeutic advances in gastroenterology. 2020; 13:1756284820934626. 